\title{
Physicochemical and Microbiological Properties of Yogurt-cheese Manufactured with Ultrafiltrated Cow's Milk and Soy Milk Blends
}

\author{
Na-Kyoung Lee ${ }^{1}$, Bo Ram Mok ${ }^{1}$, Renda Kankanamge Chaturika Jeewanthi ${ }^{1}$, \\ Yoh Chang Yoon ${ }^{1}$, and Hyun-Dong Paik ${ }^{1,2 *}$ \\ ${ }^{1}$ Department of Food Science and Biotechnology of Animal Resources, Konkuk University, Seoul 143-701, Korea \\ ${ }^{2}$ Bio/Molecular Informatics Center, Konkuk University, Seoul 143-701, Korea
}

\begin{abstract}
The objective of this study was to develop yogurt-cheese using cow's milk, ultrafiltrated cow's milk, and soy milk. The addition of soy milk and ultrafiltrated milk increased the amount of protein in the yogurt-cheese. Yogurt-cheeses were made using cheese base using $10 \%$ and $20 \%$ soy milk with raw and ultrafiltrated cow's milk, and stored at $4{ }^{\circ} \mathrm{C}$ during $2 \mathrm{wk}$. The yield of yogurt-cheeses made with added soy milk was decreased and the cutting point was delayed compared to yogurt-cheese made without soy milk. Yogurt-cheese made using ultrafiltrated cow's milk showed the highest yield. However, yogurt-cheese made with added soy milk had higher protein content and titratable acidity than yogurt-cheese made using raw and ultrafiltrated cow's milk. Fat and lactose contents in the yogurt-cheese made with added soy milk were lower. Yogurt-cheeses made with added soy milk contained several soy protein bands corresponding to the sizes of $\alpha_{2}-, \beta$-, and $\kappa$-casein band. Yogurt-cheese made with added soy milk had similar elasticity to yogurt-cheese made without soy milk but had lower cohesiveness. There was no significant difference in the number of lactic acid bacteria in the different cheeses, as all had over $8.0 \mathrm{Log} \mathrm{CFU} / \mathrm{g}$. Considering these data and the fact that proteins and fats of vegetable origin with high biological value were observed as well as unsaturated fats, yogurt-cheese made with added soy milk can be considered to be a functional food.
\end{abstract}

Key words: yogurt-cheese, soy milk, ultrafiltration, lactic acid bacteria, functional food

Received Decemver 12, 2014 / Revised February 11, 2015 / Accepted February 11, 2015

\section{Introduction}

Lactic acid bacteria (LAB) present in various dairy products are involved in a number of diverse processes such as milk protein coagulation, acceleration of acidification, production of proteinase, exopolysaccharides, aroma, and providing health-promoting properties (Golić et al., 2013; Topisirovic et al., 2006). Bifidobacterium spp. and Lactobacillus spp. are widely used as probiotic microorganisms, and other bacteria such as Enterococcus spp. as well as yeasts have been exploited as probiotic dairy products (Albenzio et al., 2013). The use of probiotic LAB is a current topic of interest in the scientific literature and represents a trend for the dairy. The probiotic cheese and yogurt were manufactured using yogurt starter and probiotic bacteria, and the role of probiotic $\mathrm{LAB}$ in the development of their physicochemical characteristics

\footnotetext{
*Corresponding author: Hyun-Dong Paik, Department of Food Science and Biotechnology of Animal Resources, Konkuk University, Seoul 143-701, Korea. Tel: +82-2-2049-6011, Fax: +822-455-3082, E-mail: hdpaik@konkuk.ac.kr
}

during storage was examined (Vinderola et al., 2009). The supplementation of cheese with probiotic bacteria represents the aggregation of added value, higher cheese yield, and benefits inherent in its composition.

Soybeans are an excellent source of high quality protein, and soy milk has been used as a milk alternative. Soy milk contains high amounts of protein, iron, unsaturated fatty acids, and niacin, but low amounts of fat, carbohydrates, and calcium compared with cow's milk (Liu, 1997). Various soy cheeses are made in many countries and have attracted much attention (Li et al., 2013; Otieno et al., 2005). Soy milk cheese has been used as a soft cheese-like product (Li et al., 2013; Liong et al., 2009; Rinaldoni et al., 2014), mozzarella cheese by adding gum arabic (Yang and Taranto, 1982), and hard cheese made with a mixture of cow's and soy milk (Abou El-Ella, 1980). The primary focus has been on making cheese from mixtures of cow's milk and soy milk; however, cheese quality is decreased proportionally with increasing levels of soy milk (Rani and Verma, 1995).

Yogurt-cheese is a creamy, soft, and spreadable cheese made by separating the whey from yogurt, and it is widely 
consumed as a spread. Yogurt-cheese is a fermented milk product popular in the Middle East and the Balkan regions. Yogurt-cheese, also called strained yogurt, labneh, or Greek yogurt, is yogurt that has been strained through a cloth, paper bag, or filter to remove the whey, giving it a consistency between that of yogurt and cheese. Yogurtcheese has increased storage quality than normal yogurt as it has higher total solid and lactic acid contents and lower fat content than normal yogurt (Kaaki et al., 2012; Yazici and Akgun, 2004).

The objective of this study was to develop soy yogurtcheese using LAB. Moreover, the process was evaluated based on yield, physicochemical properties, and the number of LAB in yogurt-cheese made using different cheese bases.

\section{Materials and Methods}

\section{Starter culture and raw materials}

The starter culture used for the yogurt-cheese was Thermophilic Y332A (Clerici Sacco International Srl, Cadorago Como, Italy), a mixed culture with Lactobacillus bulgaricus and Streptococcus thermophilus. Double strength (290 IMUC/mL) calf rennet was used (Standard Plus 900; Chr. Hansens Inc., Australia).

Raw fresh cow's milk was obtained from a Korean dairy farm and then pasteurized at $62^{\circ} \mathrm{C}$ for $30 \mathrm{~min}$ using a cheese vat. Milk ultrafiltration was carried out at $50^{\circ} \mathrm{C}$ at a pressure of 6 bar and 2 bar for the inlet and outlet, respectively (Imtiaz et al., 2013) using flat sheet GR-90PP ultrafiltration membranes made of polysulphone (Danish Separation Systems AS, Stavangervej 10, Denmark). The molecular weight cut-off range was $20 \mathrm{kDa}$. The experiment was carried out in a spiral wound-type module (DSS LabUnit M20, Alfa Laval, Denmark). The total effective surface area of the membranes was $0.036 \mathrm{~m}^{2}$. After the first filtration, the retentate was subjected to a second filtration and concentrated to $2: 1$ and 3:1 volumetric concentration ratios for cheese base (CB) 1 and $\mathrm{CB} 2$, respectively.

Mature soy beans (Baektae, white soybean) were obtained from a Korean supermarket. Raw soybeans were washed and added to a $10 \times$ volume of tap water, kept for $12 \mathrm{~h}$ at $14-20^{\circ} \mathrm{C}$ and then blended with $2 \times$ weight of distilled water at $85,000 \mathrm{rpm}$ in a blender for $5 \mathrm{~min}$. The resulting puree was then filtered through a muslin cloth. Using a dehydrator (W-60T, Hanil Electric Co., Korea), the milk was extracted from the puree. The soy milk was heated to $80-85^{\circ} \mathrm{C}$ for $30 \mathrm{~min}$ before blending it with pas- teurized cow's milk.

\section{Yogurt-cheese production}

Yogurt-cheeses were produced using various cheese bases: two types of yogurt-cheeses (S1 and S2) were made using combination of $10 \%$ and $20 \%$ soy milk, respectively, with fresh cow's milk and two type were made using combination of $10 \%$ and $20 \%$ soy milk with ultrafiltrated milk (SC1 and SC2). Cheeses were manufactured according to standard procedures (Kosikowski, 1977). The milk was tempered to $40-42^{\circ} \mathrm{C}$ before inoculation with the starter culture. After adding the required amount of rennet and starter culture, the milk was left to ripen for 2-3 $\mathrm{h}$ until the $\mathrm{pH}$ reached 4.5. The resulting curd was cut with $2 \mathrm{~cm}$ cheese knives. The curds were agitated slowly for 15-30 min while being cooked at $45^{\circ} \mathrm{C}$. The whey was then removed, and the curds were cooled at low pressure, then washed, packed, and stored at $4^{\circ} \mathrm{C}$ for $2 \mathrm{wk}$.

\section{Physicochemcial analysis of yogurt-cheese}

Yield, cutting point, moisture, protein, ash, lactose, fat, and titratable acidity were measured according to the AOAC method (2000). The yield of curd versus cheese base was calculated. The cutting point was defined as the time when the $\mathrm{pH}$ reached 4.5-4.6. Grated cheese was analyzed for protein, fat, and lactose levels. Kjeldahl's method and a modified Mojonnier method were used to measure protein and fat contents, respectively. Water-soluble extracts of the cheese were prepared using the method of Kuchroo and Fox (1982). All the chemical measurements were performed in triplicate after 0,1 , and 2 wk of ripening.

SDS-polyacrylamide gel electrophoresis (PAGE) was performed using $10 \%$ SDS polyacrylamide gel to measure the level of proteolysis. Aliquots of $0.6 \mathrm{~g}$ of each sample were diluted with $25 \mathrm{~mL}$ of $8 \mathrm{M}$ urea, and homogenized for $2 \mathrm{~min}$. These suspensions were incubated for 2 $\mathrm{h}$ in a water bath at $37^{\circ} \mathrm{C}$, and then centrifuged $10,000 \mathrm{~g}$ for $30 \mathrm{~min}$. The supernatant was then filtered using filter paper (Whatman no. 1), and the filtrates were lyophilized. Urea-SDS-PAGE was performed using a Mini-PROTEAN ${ }^{\circledR}$ Tetra system (Bio-Rad Laboratories Inc., USA) with 5\% stacking gel and $10 \%$ acrylamide separating gel. The protein molecular marker used was SeeBlue Plus2 PreStained Standard (Invitrogen, Carlsbad, CA, USA).

\section{Texture analysis of yogurt-cheese}

Texture analysis was performed to assess springiness, brittleness, gumminess, and cohesiveness at $25^{\circ} \mathrm{C}$ using a 
Rheometer (Model NRM-2001, Fudoh Kogyo Co., Japan). Aliquots of $100 \mathrm{~g}$ of each sample was put in plastic cup with $6 \mathrm{~cm}$ of inner diameter and pressed to half size. The machine was used a probe of $30 \mathrm{~mm}$ circle (No. 11), a maximum load of $2000 \mathrm{~g}$, a table speed of $60 \mathrm{~mm} / \mathrm{min}$, and an intrusion distance of $5 \mathrm{~mm}$.

\section{Enumeration of LAB of yogurt-cheese}

The number of LAB was measured using plate count agar with bromocresol purple. Aliquots were plated using 10 -fold dilutions and counted after $72 \pm 3 \mathrm{~h}$ incubation at $35 \pm 1{ }^{\circ} \mathrm{C}$.

\section{Statistical analysis}

Data were statistically evaluated by analysis of variance (ANOVA) and Duncan's multiple range test. A $p$ value < 0.05 was considered to indicate statistically significant (SAS, 2004).

\section{Results and Discussion}

\section{Composition of cheese bases}

The type of milk used for making cheese has a profound influence on the cheese composition. The constituents of milk influence the casein to fat ratio, total solids, lactose, ash, moisture levels, and the extent of acid development in the finished cheese (Traordinary Dairy, 2001). The chemical compositions of the cheese bases used in this study are shown in Table 1. An increase in soy milk concentration led to a decrease in the fat and lactose contents of the milk, as well as to an increase in the protein content. When ultrafiltrated milk was used, all components except lactose were higher than when raw milk was used.

\section{Yield and cutting point of yogurt-cheeses}

The cutting point and yield of cheeses depends on the rheological and microstructural properties of gels, such as their coagulum firmness and rearrangement capability, which in turn depend on coagulation factors, milk com-
Table 2. Comparison of yield and cutting point of yogurtcheeses

\begin{tabular}{ccc}
\hline Cheese types & Yield (\%) & Cutting point (min) \\
\hline Control & 26.67 & 240 \\
S1 & 17.92 & 320 \\
S2 & 12.53 & 360 \\
CF2 & 43.79 & 280 \\
SC1 & 14.20 & 400 \\
SC2 & 12.85 & 460 \\
\hline
\end{tabular}

Control, cheese made from raw milk; S1, cheese made from raw milk mixed with $10 \%$ soy milk; $\mathrm{S} 2$, cheese made from raw milk mixed with $20 \%$ soy milk; CF2, cheese made from ultrafiltrated milk; SC1, cheese made from ultrafiltrated milk mixed with $10 \%$ soy milk; SC2, cheese made from ultrafiltrated milk mixed with $20 \%$ soy milk.

position, and milk pretreatment (Castillo, 2006). The yield of cutting point of the yogurt-cheeses are shown in Table 2. The yield of cheese made from raw milk (control) and cheese made from ultrafiltrated milk (CF2) was $26.67 \%$ and $43.79 \%$, respectively. The cutting point of the control and CF2 cheese was $240 \mathrm{~min}$ and $280 \mathrm{~min}$, respectively. The addition of soy milk increased the cutting point, but the yield decreased as increasing amounts of soy milk were added.

\section{Yogurt-cheese characterization}

The compositions of the different types of yogurt-cheese are presented in Table 3. The addition of soy milk and ultrafiltered cow's milk significantly increased the ash and protein levels. Total solid and ash contents were 21.93$29.23 \%$ and $0.854-1.337 \%$, respectively, and decreased over the storage period. The lactose content of the control cheese was $7.63 \%$. During storage, the lactose content decreased significantly for all cheese types made with added soy milk $(p<0.05)$. The highest lactose content of $8.58 \%$ was observed in CF2. The protein content in the cheeses made from soy milk and fresh cow's milk was 12.77$15.85 \%$, while in cheeses made from soy milk and ultrafiltrated cow's milk, it was $13.9-16.9 \%$. The protein content in the yogurt-cheeses decreased over the storgae

Table 1. General components of cheese bases

\begin{tabular}{ccccc}
\hline \multirow{2}{*}{ Cheese base } & \multicolumn{3}{c}{ Components } \\
\cline { 2 - 5 } & Total solid (\%) & Lactose (\%) & Protein (\%) & Fat (\%) \\
\hline Raw milk & $12.97 \pm 0.18^{\mathrm{a}}$ & $5.22 \pm 0.12^{\mathrm{a}}$ & $3.22 \pm 0.04^{\mathrm{c}}$ & $3.78 \pm 0.11^{\mathrm{a}}$ \\
$10 \%$ Soy milk & $12.41 \pm 0.15^{\mathrm{b}}$ & $4.57 \pm 0.18^{\mathrm{b}}$ & $3.85 \pm 0.06^{\mathrm{b}}$ & $3.26 \pm 0.30^{\mathrm{b}}$ \\
$20 \%$ Soy milk & $12.18 \pm 0.19^{\mathrm{c}}$ & $4.46 \pm 0.07^{\mathrm{c}}$ & $4.15 \pm 0.11^{\mathrm{a}}$ & $2.80 \pm 0.12^{\mathrm{c}}$ \\
CB2 & $20.75 \pm 0.19^{\mathrm{a}}$ & $5.01 \pm 0.27^{\mathrm{a}}$ & $6.44 \pm 0.07^{\mathrm{c}}$ & $7.56 \pm 0.16^{\mathrm{a}}$ \\
$10 \%$ Soy milk & $19.45 \pm 0.18^{\mathrm{b}}$ & $4.19 \pm 0.13^{\mathrm{b}}$ & $7.96 \pm 0.10^{\mathrm{b}}$ & $6.42 \pm 0.25^{\mathrm{b}}$ \\
$20 \%$ Soy milk & $18.86 \pm 0.06^{\mathrm{c}}$ & $4.11 \pm 0.09^{\mathrm{c}}$ & $8.38 \pm 0.21^{\mathrm{a}}$ & $5.51 \pm 0.13^{\mathrm{c}}$ \\
\hline
\end{tabular}

${ }^{\mathrm{a}-\mathrm{c}}$ Values with different letters in the same column are significantly different $(p<0.05)$. 
Table 3. Composition change of yogurt-cheeses made from different blends during storage at $4^{\circ} \mathrm{C}$

\begin{tabular}{|c|c|c|c|c|c|c|c|}
\hline \multirow{2}{*}{ Composition } & \multirow{2}{*}{$\begin{array}{c}\text { Storage } \\
\text { period (wk) }\end{array}$} & \multicolumn{6}{|c|}{ Cheese types } \\
\hline & & Control & S1 & S2 & CF2 & SC1 & SC2 \\
\hline \multirow{3}{*}{$\begin{array}{l}\text { Total solid } \\
\text { (\%) }\end{array}$} & 0 & $26.7 \pm 0.30^{\mathrm{c}}$ & $21.93 \pm 0.36^{\mathrm{c}}$ & $25.53 \pm 0.18^{\mathrm{c}}$ & $29.23 \pm 0.24^{\mathrm{c}}$ & $24.3 \pm 0.08^{\mathrm{c}}$ & $26.19 \pm 0.32^{\mathrm{c}}$ \\
\hline & 1 & $27.02 \pm 0.19^{b}$ & $25.03 \pm 0.10^{\mathrm{b}}$ & $27.61 \pm 0.09^{b}$ & $30.45 \pm 0.09^{b}$ & $26.47 \pm 0.18^{b}$ & $29.86 \pm 0.04^{b}$ \\
\hline & 2 & $29.98 \pm 0.13^{\mathrm{a}}$ & $27.16 \pm 0.17^{\mathrm{a}}$ & $29.13 \pm 0.19^{\mathrm{a}}$ & $31.14 \pm 0.29^{\mathrm{a}}$ & $29 \pm 0.15^{\mathrm{a}}$ & $30.6 \pm 0.14^{\mathrm{a}}$ \\
\hline \multirow{3}{*}{$\begin{array}{l}\text { Ash } \\
(\%)\end{array}$} & 0 & $0.854 \pm 0.07^{\mathrm{a}}$ & $0.865 \pm 0.13^{\mathrm{a}}$ & $0.943 \pm 0.13^{\mathrm{a}}$ & $1.037 \pm 0.05^{\mathrm{a}}$ & $0.903 \pm 0.05^{\mathrm{a}}$ & $1.337 \pm 0.01^{\mathrm{a}}$ \\
\hline & 1 & $0.741 \pm 0.05^{\mathrm{b}}$ & $0.753 \pm 0.10^{\mathrm{b}}$ & $0.905 \pm 0.22^{\mathrm{a}}$ & $0.955 \pm 0.01^{\mathrm{a}}$ & $0.895 \pm 0.08^{\mathrm{a}}$ & $1.19 \pm 0.19^{c}$ \\
\hline & 2 & $0.761 \pm 0.13^{b}$ & $0.702 \pm 0.09^{\mathrm{c}}$ & $0.833 \pm 0.14^{\mathrm{b}}$ & $0.826 \pm 0.01^{\mathrm{a}}$ & $0.786 \pm 0.02^{\mathrm{b}}$ & $1.266 \pm 0.16^{\mathrm{b}}$ \\
\hline \multirow{3}{*}{$\begin{array}{c}\text { Lactose } \\
(\%)\end{array}$} & 0 & $7.63 \pm 0.94^{\mathrm{a}}$ & $4.53 \pm 0.06^{\mathrm{a}}$ & $4.09 \pm 0.23^{\mathrm{a}}$ & $8.58 \pm 1.84^{\mathrm{a}}$ & $5.79 \pm 0.01^{\mathrm{a}}$ & $4.27 \pm 0.17^{\mathrm{a}}$ \\
\hline & 1 & $6.72 \pm 0.41^{\mathrm{b}}$ & $2.8 \pm 0.06^{\mathrm{b}}$ & $2.3 \pm 0.56^{b}$ & $6.76 \pm 1.84^{\mathrm{b}}$ & $3.06 \pm 0.70^{\mathrm{b}}$ & $2.71 \pm 1.38^{\mathrm{b}}$ \\
\hline & 2 & $4.47 \pm 0.43^{\mathrm{c}}$ & $2.21 \pm 0.07^{\mathrm{c}}$ & $1.88 \pm 0.64^{\mathrm{c}}$ & $4.31 \pm 0.33^{\mathrm{c}}$ & $2.81 \pm 0.10^{\mathrm{c}}$ & $2.12 \pm 0.14^{\mathrm{c}}$ \\
\hline \multirow{3}{*}{$\begin{array}{c}\text { Protein } \\
(\%)\end{array}$} & 0 & $12.77 \pm 2.26^{\mathrm{a}}$ & $14.71 \pm 2.26^{\mathrm{a}}$ & $15.85 \pm 1.27^{\mathrm{a}}$ & $13.9 \pm 0.95^{\mathrm{a}}$ & $15.36 \pm 3.10^{\mathrm{a}}$ & $16.9 \pm 1 / 02^{\mathrm{a}}$ \\
\hline & 1 & $12.34 \pm 1.19^{b}$ & $14.14 \pm 1.19^{b}$ & $15.41 \pm 0.57^{\mathrm{b}}$ & $13.68 \pm 1.72^{b}$ & $15.08 \pm 1.96^{\mathrm{a}}$ & $15.65 \pm 1.18^{b}$ \\
\hline & 2 & $9.49 \pm 0.11^{\mathrm{c}}$ & $13.18 \pm 0.11^{\mathrm{c}}$ & $14.04 \pm 0.95^{\mathrm{c}}$ & $11.45 \pm 1.30^{\mathrm{c}}$ & $14.64 \pm 2.31^{\mathrm{a}}$ & $15.27 \pm 0.92^{\mathrm{c}}$ \\
\hline \multirow{3}{*}{$\begin{array}{l}\text { Fat } \\
(\%)\end{array}$} & 0 & $12.15 \pm 0.18^{\mathrm{a}}$ & $11.05 \pm 0.12^{\mathrm{a}}$ & $10.20 \pm 0.48^{\mathrm{b}}$ & $12.18 \pm 0.12^{\mathrm{b}}$ & $11.67 \pm 0.15^{\mathrm{a}}$ & $10.92 \pm 027^{\mathrm{a}}$ \\
\hline & 1 & $11.86 \pm 0.29^{b}$ & $10.57 \pm 0.16^{\mathrm{b}}$ & $10.47 \pm 0.19^{\mathrm{a}}$ & $12.31 \pm 0.12^{\mathrm{a}}$ & $11.49 \pm 0.39^{b}$ & $10.71 \pm 0.25^{\mathrm{b}}$ \\
\hline & 2 & $10.85 \pm 0.19^{c}$ & $9.49 \pm 0.18^{\mathrm{c}}$ & $8.97 \pm 0.21^{\mathrm{c}}$ & $11.76 \pm 0.16^{\mathrm{c}}$ & $9.78 \pm 0.18^{c}$ & $9.57 \pm 0.17^{\mathrm{c}}$ \\
\hline \multirow{3}{*}{$\begin{array}{l}\text { Titratable } \\
\text { acidity }\end{array}$} & 0 & $0.110 \pm 0.19^{b}$ & $0.145 \pm 0.08^{\mathrm{b}}$ & $0.160 \pm 0.01^{\mathrm{c}}$ & $0.082 \pm 0.03^{b}$ & $0.141 \pm 0.12^{b}$ & $0.150 \pm 0.10^{\mathrm{b}}$ \\
\hline & 1 & $0.111 \pm 0.04^{\mathrm{b}}$ & $0.159 \pm 0.06^{\mathrm{b}}$ & $0.174 \pm 0.11^{\mathrm{b}}$ & $0.099 \pm 0.07^{\mathrm{b}}$ & $0.152 \pm 0.10^{\mathrm{a}}$ & $0.154 \pm 0.03^{\mathrm{b}}$ \\
\hline & 2 & $0.161 \pm 0.11^{\mathrm{a}}$ & $0.174 \pm 0.03^{\mathrm{a}}$ & $0.194 \pm 0.06^{\mathrm{a}}$ & $0.159 \pm 0.09^{\mathrm{a}}$ & $0.156 \pm 0.10^{\mathrm{a}}$ & $0.163 \pm 0.06^{\mathrm{a}}$ \\
\hline
\end{tabular}

${ }^{\mathrm{a}-\mathrm{c}}$ Values with different letters in the same column are significantly different $(p<0.05)$.

Control, cheese made from raw milk; S1, cheese made from raw milk mixed with $10 \%$ soy milk; S2, cheese made from raw milk mixed with $20 \%$ soy milk; CF2, cheese made from ultrafiltrated milk; SC1, cheese made from ultrafiltrated milk mixed with $10 \%$ soy milk; SC2, cheese made from ultrafiltrated milk mixed with $20 \%$ soy milk.

period. The fat content was $10.20-12.18 \%$ and decreased over the storage period. An increased proportion of soy milk led to a decrease in fat composition. In addition, soy milk contains essential polyunsaturated fatty acids included linoleica, linolenic, and arachidonic acid (GatchalianYee, 2011) that have a high biological value similar to those derived from meat, fish, or eggs, and also are capable of lowering triglyceridae and cholesterol (Rinaldoni et al., 2014).

Urea-SDS-PAGE was used to define the proteolysis of the yogurt-cheeses (Data not shown). The molecular weight of casein has been reported to be $30 \mathrm{kDa}$. Whereas all the yogurt-cheeses had band of approximately $30 \mathrm{kDa}$, soy cheese had other bands with molecuar weights of approximately $45 \mathrm{kDa}$ and $66 \mathrm{kDa}$, which must have originated from the soy milk rather than the cow's milk. Soy protein is composed of glycinin and $\beta$-conglycinin, and the molecular weight of glycinin has been reported as $350 \mathrm{kDa}$, with various subunits of 37-42 $\mathrm{kDa}$ and 17-20 kDa (Adachi et al., 2003).

\section{Rheological properties of yogurt-cheeses}

The rheological properties of yogurt-cheeses include their springiness, cohesiveness, chewiness, and brittleness, which are shown in Table 4. The cheeses were ranked in terms of springiness and cohesiveness in the following order: $\mathrm{CF} 2>$ control $>\mathrm{SC} 1>\mathrm{SC} 2>\mathrm{S} 1>\mathrm{S} 2$. The springiness and cohesiveness of the cheeses were not influenced by the ratio of soy milk used to prepare them. However, the cheeses were ranked in terms of chewiness in the following order: control $>\mathrm{CF} 2>\mathrm{SC} 1>\mathrm{SC} 2>\mathrm{S} 1>\mathrm{S} 2$, and in terms of brittleness in the following order: $\mathrm{SC} 2>\mathrm{SC} 1$ $>\mathrm{S} 2>\mathrm{S} 1>\mathrm{CF} 2>$ control. Thus, this experiment did not show a significant difference in the rheological characteristics between the $10 \%$ and $20 \%$ soy milk-blended cheeses. The springiness, cohesiveness, chewiness, and brittleness of the cheeses increased over the storage period.

\section{LAB of yogurt-cheese}

Fermented dairy products must have $10^{7} \mathrm{CFU} / \mathrm{mL}$ of probiotic bacteria in order to provide health benefits in the gastrointestinal tract when consumed (Ouwehand and Salminen, 1998). The total counts of LAB in yogurtcheese are shown in Table 5. The total counts of LAB varied from $8.44 \mathrm{Log} \mathrm{CFU} / \mathrm{g}$ to $8.91 \mathrm{Log} \mathrm{CFU} / \mathrm{g}$ and remained at levels over $8.0 \mathrm{Log} \mathrm{CFU} / \mathrm{g}$ for the $2 \mathrm{wk}$ of storage. Yogurt must have over $6.0 \mathrm{Log} \mathrm{CFU} / \mathrm{g}$ at the time of consumption to provide probiotic effects (Vinderola and Reinheimer, 2000). Similar to the yogurt-cheeses in this study, soy-based cream cheese was reported to contain more than 7.0 Log CFU/g during storage (Liong et al., 2009). Therefore, the probiotic effect of yogurt-cheese 
Table 4. Texture of yogurt-cheeses made from different blends during storage at $4^{\circ} \mathrm{C}$

\begin{tabular}{|c|c|c|c|c|c|c|c|}
\hline \multirow{2}{*}{ Composition } & \multirow{2}{*}{$\begin{array}{c}\text { Storage } \\
\text { period (wk) }\end{array}$} & \multicolumn{6}{|c|}{ Cheese types } \\
\hline & & Control & S1 & S2 & CF2 & $\mathrm{SC} 1$ & $\mathrm{SC} 2$ \\
\hline \multirow{4}{*}{$\begin{array}{l}\text { Springiness } \\
(\mathrm{m})\end{array}$} & 0 & $0.77 \pm 0.09^{\mathrm{a}}$ & $0.71 \pm 0.10^{\mathrm{a}}$ & $0.71 \pm 0.05^{\mathrm{a}}$ & $0.88 \pm 0.08^{\mathrm{a}}$ & $0.79 \pm 0.02^{\mathrm{a}}$ & $0.78 \pm 0.10^{\mathrm{a}}$ \\
\hline & 1 & $0.77 \pm 0.17^{\mathrm{a}}$ & $0.67 \pm 0.18^{\mathrm{a}}$ & $0.67 \pm 0.08^{\mathrm{a}}$ & $0.84 \pm 0.10^{\mathrm{a}}$ & $0.71 \pm 0.03^{\mathrm{a}}$ & $0.70 \pm 0.03^{\mathrm{a}}$ \\
\hline & 2 & $0.75 \pm 0.01^{\mathrm{a}}$ & $0.61 \pm 0.12^{\mathrm{b}}$ & $0.56 \pm 0.05^{\mathrm{b}}$ & $0.76 \pm 0.10^{\mathrm{b}}$ & $0.71 \pm 0.02^{\mathrm{a}}$ & $0.69 \pm 0.11^{\mathrm{a}}$ \\
\hline & 0 & $0.88 \pm 0.12^{\mathrm{a}}$ & $0.80 \pm 0.05^{\mathrm{a}}$ & $0.79 \pm 0.09^{\mathrm{a}}$ & $0.94 \pm 0.12^{\mathrm{a}}$ & $0.88 \pm 0.07^{\mathrm{a}}$ & $0.86 \pm 0.06^{\mathrm{a}}$ \\
\hline \multirow[t]{2}{*}{ Cohesiveness } & 1 & $0.83 \pm 0.08^{\mathrm{a}}$ & $0.76 \pm 0.15^{\mathrm{a}}$ & $0.74 \pm 0.17^{\mathrm{a}}$ & $0.92 \pm 0.08^{\mathrm{a}}$ & $0.86 \pm 0.04^{\mathrm{a}}$ & $0.84 \pm 0.06^{\mathrm{a}}$ \\
\hline & 2 & $0.73 \pm 0.03^{b}$ & $0.69 \pm 0.09^{\mathrm{a}}$ & $0.64 \pm 0.01^{\mathrm{b}}$ & $0.87 \pm 0.03^{\mathrm{a}}$ & $0.75 \pm 0.02^{b}$ & $0.73 \pm 0.07^{\mathrm{b}}$ \\
\hline \multirow{3}{*}{$\begin{array}{c}\text { Chewiness } \\
\text { (g) }\end{array}$} & 0 & $97.30 \pm 4.01^{\mathrm{a}}$ & $80.11 \pm 2.33^{\mathrm{a}}$ & $78.83 \pm 3.59^{\mathrm{a}}$ & $90.57 \pm 3.25^{\mathrm{a}}$ & $85.44 \pm 2.10^{\mathrm{a}}$ & $84.10 \pm 1.41^{\mathrm{a}}$ \\
\hline & 1 & $96.81 \pm 2.83^{\mathrm{a}}$ & $75.69 \pm 4.43^{\mathrm{a}}$ & $75.54 \pm 5.06^{\mathrm{a}}$ & $91.45 \pm 3.20^{\mathrm{a}}$ & $86.03 \pm 2.72^{\mathrm{a}}$ & $83.98 \pm 1.04^{\mathrm{a}}$ \\
\hline & 2 & $83.12 \pm 1.66^{\mathrm{b}}$ & $65.06 \pm 2.73^{b}$ & $65.17 \pm 2.53^{\mathrm{b}}$ & $79.43 \pm 2.30^{b}$ & $75.19 \pm 1.01^{\mathrm{b}}$ & $72.03 \pm 0.96^{\mathrm{b}}$ \\
\hline \multirow{3}{*}{$\begin{array}{l}\text { Brittleness } \\
\text { (N) }\end{array}$} & 0 & $0.91 \pm 0.16^{\mathrm{a}}$ & $1.00 \pm 0.09^{\mathrm{a}}$ & $1.25 \pm 0.23^{\mathrm{a}}$ & $0.97 \pm 0.13^{\mathrm{a}}$ & $1.52 \pm 0.15^{\mathrm{a}}$ & $1.80 \pm 0.49^{\mathrm{a}}$ \\
\hline & 1 & $0.79 \pm 0.14^{b}$ & $0.97 \pm 0.02^{\mathrm{a}}$ & $1.10 \pm 0.12^{\mathrm{b}}$ & $0.83 \pm 0.14^{\mathrm{b}}$ & $1.47 \pm 0.16^{\mathrm{a}}$ & $1.65 \pm 0.11^{\mathrm{b}}$ \\
\hline & 2 & $0.64 \pm 0.08^{\mathrm{c}}$ & $0.80 \pm 0.05^{\mathrm{b}}$ & $0.93 \pm 0.05^{\mathrm{c}}$ & $0.78 \pm 0.05^{\mathrm{b}}$ & $1.26 \pm 0.13^{\mathrm{b}}$ & $1.53 \pm 0.60^{\mathrm{c}}$ \\
\hline \multirow{3}{*}{$\begin{array}{l}\text { Fat } \\
(\%)\end{array}$} & 0 & $12.15 \pm 0.18^{\mathrm{a}}$ & $11.05 \pm 0.12^{\mathrm{a}}$ & $10.20 \pm 0.48^{\mathrm{b}}$ & $12.18 \pm 0.12^{\mathrm{b}}$ & $11.67 \pm 0.15^{\mathrm{a}}$ & $10.92 \pm 027^{\mathrm{a}}$ \\
\hline & 1 & $11.86 \pm 0.29^{\mathrm{b}}$ & $10.57 \pm 0.16^{\mathrm{b}}$ & $10.47 \pm 0.19^{\mathrm{a}}$ & $12.31 \pm 0.12^{\mathrm{a}}$ & $11.49 \pm 0.39^{\mathrm{b}}$ & $10.71 \pm 0.25^{\mathrm{b}}$ \\
\hline & 2 & $10.85 \pm 0.19^{c}$ & $9.49 \pm 0.18^{\mathrm{c}}$ & $8.97 \pm 0.21^{\mathrm{c}}$ & $11.76 \pm 0.16^{\mathrm{c}}$ & $9.78 \pm 0.18^{\mathrm{c}}$ & $9.57 \pm 0.17^{\mathrm{c}}$ \\
\hline \multirow{3}{*}{$\begin{array}{l}\text { Titratable } \\
\text { acidity }\end{array}$} & 0 & $0.110 \pm 0.19^{\mathrm{b}}$ & $0.145 \pm 0.08^{b}$ & $0.160 \pm 0.01^{\mathrm{c}}$ & $0.082 \pm 0.03^{\mathrm{b}}$ & $0.141 \pm 0.12^{\mathrm{b}}$ & $0.150 \pm 0.10^{\mathrm{b}}$ \\
\hline & 1 & $0.111 \pm 0.04^{\mathrm{b}}$ & $0.159 \pm 0.06^{\mathrm{b}}$ & $0.174 \pm 0.11^{\mathrm{b}}$ & $0.099 \pm 0.07^{\mathrm{b}}$ & $0.152 \pm 0.10^{\mathrm{a}}$ & $0.154 \pm 0.03^{b}$ \\
\hline & 2 & $0.161 \pm 0.11^{\mathrm{a}}$ & $0.174 \pm 0.03^{\mathrm{a}}$ & $0.194 \pm 0.06^{\mathrm{a}}$ & $0.159 \pm 0.09^{\mathrm{a}}$ & $0.156 \pm 0.10^{\mathrm{a}}$ & $0.163 \pm 0.06^{\mathrm{a}}$ \\
\hline
\end{tabular}

${ }^{\mathrm{a}-\mathrm{c}}$ Values with different letters in the same column are significantly different $(p<0.05)$.

Control, cheese made from raw milk; S1, cheese made from raw milk mixed with $10 \%$ soy milk; S2, cheese made from raw milk mixed with $20 \%$ soy milk; CF2, cheese made from ultrafiltrated milk; SC1, cheese made from ultrafiltrated milk mixed with $10 \%$ soy milk; SC2, cheese made from ultrafiltrated milk mixed with $20 \%$ soy milk.

Table 5. The number of lactic acid bacteria of yogurt-cheeses made from different blends during storage at $4^{\circ} \mathrm{C}$

\begin{tabular}{cccc}
\hline \multirow{2}{*}{ Cheese types } & \multicolumn{3}{c}{ Storage period (wk) } \\
\cline { 2 - 4 } & 0 & 1 & 2 \\
\hline Control & $8.91 \pm 0.08^{\mathrm{a}}$ & $8.87 \pm 0.08^{\mathrm{a}}$ & $8.82 \pm 0.08^{\mathrm{a}}$ \\
S1 & $8.71 \pm 0.01^{\mathrm{a}}$ & $8.69 \pm 0.01^{\mathrm{a}}$ & $8.66 \pm 0.01^{\mathrm{a}}$ \\
S2 & $8.44 \pm 0.13^{\mathrm{a}}$ & $8.25 \pm 0.12^{\mathrm{b}}$ & $8.00 \pm 0.12^{\mathrm{c}}$ \\
$\mathrm{CF} 2$ & $8.77 \pm 0.02^{\mathrm{a}}$ & $8.76 \pm 0.02^{\mathrm{a}}$ & $8.75 \pm 0.02^{\mathrm{a}}$ \\
SC1 & $8.49 \pm 0.12^{\mathrm{a}}$ & $8.09 \pm 0.12^{\mathrm{b}}$ & $8.13 \pm 0.12^{\mathrm{b}}$ \\
SC2 & $8.44 \pm 0.14^{\mathrm{a}}$ & $8.01 \pm 0.13^{\mathrm{c}}$ & $8.07 \pm 0.13^{\mathrm{b}}$ \\
\hline
\end{tabular}

${ }^{\mathrm{a}-\mathrm{c}}$ Values with different letters in the same column are significantly different $(p<0.05)$.

Control, cheese made from raw milk; S1, cheese made from raw milk mixed with $10 \%$ soy milk; S2, cheese made from raw milk mixed with $20 \%$ soy milk; CF2, cheese made from ultrafiltrated milk; SC1, cheese made from ultrafiltrated milk mixed with $10 \%$ soy milk; SC2, cheese made from ultrafiltrated milk mixed with $20 \%$ soy milk.

could be anticipated by maintaining a viable LAB community during storage.

\section{Conclusions}

Yogurt-cheese was produced using cow's milk, ultrafiltrated cow's milk, and soy milk. The $\mathrm{pH}$ of yogurt-cheese curds made with added soy milk decreased more slowly than that of yogurt-cheese made using cow's milk. The yogurt-cheeses made with added soy milk had a higher protein and ash content, and a lower fat content than the cheeses made using cow's milk alone, and also contained several soy protein with molecular weights corresponding to $\alpha_{2}-, \beta$-, and $\kappa$-casein. In addition, yogurt-cheese can be a suitable source of probiotic LAB. These data suggest that yogurt-cheese made using soy milk could be considered as a functional food with high biological value and unsaturated fats.

\section{Acknowledgements}

This work was supported by Priority Research Centers Program through the National Research Foundation of Korea (NRF) funded by the Ministry of Education, Science and Technology (2009-0093824).

\section{References}

1. Abou El-Ella, W. M. (1980) Hard cheese substitute from soy milk. J. Food Sci. 45, 1777-1778.

2. Adachi, M., Kanamori, J., Masuda, T., Yagasaki, K., Kitamura, K., Mikami, B., and Utsumi, S. (2003) Crystal structure of soybean 11S globulin: glycinin A3B4 homohexamer. Proc. Natl. Acad. Sci. USA 100, 7395-7400.

3. Albenzio, M., Santillo, A., Caroprese, M., Ruggieri, D., Napolitano, F., and Sevi, A. (2013) Physicochemical properties 
of Scamorza ewe milk cheese manufactured with different probiotic cultures. J. Dairy Sci. 96, 2781-2791.

4. Association of Official Analysis Chemists (2000) Official Methods of Analysis of Intl. (17th ed.). Gaithersburg, M.D.: AOAC Intl.

5. Castillo, M. (2006) Cutting time prediction methods in cheese making. In: Heldman D, editor. Encyclopedia of agricultural, food, and biological engineering. Boca Raton, FL: Taylor \& Francis Group. pp. 1-7.

6. Gatchalian-Yee, M. V. (2011) Effects of undigested fraction of soybean protein on lipid metabolism in Brown Norway rats with different age groups. Asia Life Sci. 20, 77-83.

7. Golić, N.,Čadež, N., Terzić-Vidojević, A., Šáuransk, H., Beganović, J., Lozo, J., Kos, B., Šušković, J., Raspor, P., and Toposiroviæ, J. (2013) Evaluation of lactic acid bacteria and yeast diversity in traditional white pickled and fresh soft cheeses from the mountain regions of Serbia and lowland regions of Croatia. Int. J. Food Microbiol. 166, 294-300.

8. Imtiaz, H. A., Bell, E., and Grandison, A. S. (2013) Mozzarella-type curd made from Buffalo, cows' and ultrafiltered cows' milk. 1. rheology and Microstructure. Food Bioprocess Tec. 6, 1729-1740.

9. Kaaki, D., Baghdadi, O. K., Najm, N. E., and Olabi, A. (2012) Preference mapping of commercial Labneh (strained yogurt) products in the Lebanese market. J. Dariy Sci. 95, 521-532.

10. Kosikowski, F. V. (1977) Process cheese and related types. In: Cheese and fermented milk foods. Ann Arbor, MI. Edwards Brothers, Inc. pp. 382-406.

11. Kuchroo, C. N. and Fox, P. F. (1982) Soluble nitrogen in Cheddar cheese, comparison of extraction procedures. Milchwissenschaft 37, 331-335.

12. Li, G., Xia, Y., Zhou, L., and Xie, J. (2013) Evaluation of the rheological, textural, microstructural and sensory properties of soy cheese spreads. Food Bioprod. Process. 91, 429-439.

13. Liong, M. T., Easa, A. M., Lim, P. T., and Kang, J. Y. (2009) Survival, growth characteristics and bioactive potential of Lactobacillus acidophilus in a soy-based cream cheese. $J$. Sci. Food Agic. 89, 1382-1391.

14. Liu, K. (1997) Chemistry and nutritional value of soybean components. In: Soybean chemistry, technology and utiliza- tion. New York: Chapman and Hall's International Resource Center. pp. 26-36.

15. Otieno, D., Ashton, J., and Shah, N. E. (2005) Stability of $\beta$ glucosidase activity produced by Bifidobacterium and Lactobacillus spp. in fermented soymilk during processing and storage. J. Food Sci. 70, M236-M241.

16. Ouwehand, A. C. and Salminen, S. J. (1998) The health effects of culture milk products with viable and non-viable bacteria. Int. Dairy J. 8, 491-500.

17. Rani, M. and Verma, N. S. (1995) Changes in organoleptic quality during ripening of cheese made from cows and soya milk blends, using microbial rennet. Food Chem. 54, 369-375.

18. Rinaldoni, A. N., Palatnik, D. R., Zaritzky, N., and Campderrós, M. E. (2014) Soft cheese-like product development enriched with soy protein concentrates. LWT-Food Sci. Technol. 55, 139-147.

19. SAS Institute. (2004) SAS/STAT 9.1 User's Guide. SAS Institute Inc., Cary, NC.

20. Topisirovic, L., Kojic, M., Fira, D., Golic, N., Strahinic, I., and Lozo, J. (2006) Potential of lactic acid bacteria isolated from specific natural niches in food production and preservation. Int. J. Food Microbiol. 112, 230-235.

21. Traordinary Dairy. (2001) Improving cheese quality: Researching the origin and control of common defects. http://www. extradordinary dairy.com. Accessed Oct. 20, 2006.

22. Vinderola, C. G. and Reinheimer, J. A. (2000) Enumeration of Lactobacillus casei in the presence of L. acidophilus, Bifidobacteria and lactic starter bacteria in fermented dairy products. Int. Dairy J. 10, 271-275.

23. Vinderola, G., Prosello, W., Molinari, F., Ghiberto, D., and Reinheimer, J. (2009) Growth of Lactobacillus paracasei A13 in Argentinian probiotic cheese and its impact on the characteristics of the product. Int. J. Food Microbiol. 135, 171-174.

24. Yang, C. S. T. and Taranto, M. V. (1982) Textural properties of mozzarella cheese analogs manufactured from soybean. $J$. Food Sci. 47, 906-910.

25. Yazici, F. and Akgum, A. (2004) Effects of some protein based fat replacers on physical, chemical, textural, and sensory properties of strained yogurt. J. Food Eng. 62, 245-254. 